\title{
Shelf Life of Custard Apple Treated with 1- Methylciclopropene - an Antagonist to the Ethylene Action
}

\author{
Guilherme Benassi ${ }^{1}$, Guilherme Augusto Simões Francischini Correa ${ }^{1}$, Ricardo Alfredo \\ Kluge $^{2,3 *}$ and Angelo Pedro Jacomino ${ }^{1,3}$ \\ ${ }^{1}$ Depto. de Produção Vegetal; USP; ESALQ. ${ }^{2}$ Depto. de Ciências Biológicas; USP; ESALQ; C. P. 9; 13418-900; \\ Piracicaba - SP - Brazil. ${ }^{3}$ Bolsista $C N P q$
}

\begin{abstract}
Custard apple (Annona squamosa L.) presents very short storage life at room temperature, in part due to heavy losses in firmness. This process is associated with the production and action of the hormone ethylene. In order to retard the ripening evolution in custard apple, fruits were treated with the competitive ethylene antagonist 1-methycyclopropene (1-MCP) at concentrations of 0, 30, 90, 270 or 810 $n L L^{-1}$ for $12 \mathrm{~h}$ at $25^{\circ} \mathrm{C}$ and then stored at $25^{\circ} \mathrm{C}$ for four days. The soluble solids content (SSC), firmness and percentage of ripe fruits (firmness $\leq 0.5 \mathrm{~kg}$ ) were determined during the experimental period. There were no differences among treatments as to the SSC. Fruits treated with $810 \mathrm{~nL} L^{-1}$ of 1-MCP showed higher firmness than the control fruits. Both, non-treated or treated fruits with 30 or $90 \mathrm{~nL} L^{-1}$ ripened faster than fruits treated with 1-MCP at higher concentrations.
\end{abstract}

Key words: Ripening, storage, firmness, Annona squamosa

\section{INTRODUCTION}

Custard apple (Annona squamosa L.) is a tropical fruit which shows very short storage life at room temperature due to its fast ripening. It presents climacteric behavior, high respiration rate and ethylene production (Pal and Kumar, 1995; Prasanna et al., 2000). The fast fruit softening (firmness loss) is the main characteristic reducing the fruit's quality and commercialization.

Ethylene $\left(\mathrm{C}_{2} \mathrm{H}_{4}\right)$ is well documented as being the ripening hormone of climacteric fruits. At a certain maturation stage, ethylene is linked to its bindingsite in the cell and promotes several alterations which culminate in the ripening and senescence of fruits (Burg and Burg, 1967; Lelièvre et al., 1997a).
Such ethylene actions can be blocked by some compounds, such as 2.5-norbornadiene (NDB) and diazocyclopentadiene (DACP), which, when linked to the ethylene binding-site, avoid its action. Blankenship and Sisler (1989 and 1993) and Gong and Tian (1998) observed that NDB and DACP delayed the softening and ripening in apples. However, none of these products are commercially acceptable due to toxicity and manufacturing concerns (Fan et al., 1999).

The 1-methylcyclopropene (1-MCP or $\mathrm{C}_{4} \mathrm{H}_{6}$ ) is a potent inhibitor of the ethylene binding-site, acting as an antagonist (Sisler and Serek, 1997). The 1MCP has been formulated into a powder that releases its active ingredient when mixed with

\footnotetext{
* Author for correspondence
} 
water at $40-60^{\circ} \mathrm{C}$. This nontoxic compound can be used at low concentrations $\left(\mathrm{nL} \mathrm{L}^{-1}\right)$.

It has been reported that 1-MCP improved the shelf life of cut flowers and potted plants (Serek et al., 1994 and 1995; Porat et al., 1995; Sisler et al., 1996) and retarded the ripening of several climacteric fruits (Lelièvre et al., 1997b; Sisler and Serek, 1997; Abdi et al., 1998; Golding et al., 1998; Fan et al., 1999 and 2000; Feng et al., 2000; Jiang et al., 1999;). The objective of this work was to study the responses of custard apple to 1-MCP application during storage at room temperature.

\section{MATERIAL AND METHODS}

Custard apples (Anonna squamosa L.) were treated with Agrofresh $^{\mathrm{TM}}$, in powder form, having $0.14 \%$ of the active ingredient 1-MCP. The following 1MCP concentrations were used: $0,30,90,270$ and $810 \mathrm{~nL} \mathrm{~L}^{-1}\left(0,1.34,4.02,12.05\right.$ and $36.16 \mathrm{nmol} \mathrm{L}^{-}$ 1 , respectively). In order to achieve the above 1MCP concentrations inside the chambers, Agrofresh $^{\mathrm{TM}}$ powder was placed in sealed flasks $\left(0.00016 \mathrm{~g}\right.$ of Agrofresh ${ }^{\mathrm{TM}}$ produce $100 \mathrm{~nL} \mathrm{~L}^{-1}$ of 1-MCP). Twenty milliliters of water at $50^{\circ} \mathrm{C}$ were added to the flasks, which were stirred until the complete dissolution of the compound. Then, the flasks were opened in the chambers, which were immediately sealed to avoid gas loss. Fruits were exposed to the gas released by the product during a 12-hour exposure period at $25^{\circ} \mathrm{C}$ in hermetic chambers. After 12 hours of treatment, the chambers were opened and the fruits were kept at room temperature $\left(25^{\circ} \mathrm{C}\right)$.

The fruits were daily evaluated during four days at room temperature $\left(25^{\circ} \mathrm{C}\right)$. Firmness was measured on two opposite sides of fruits by means of a 4mm-pointed tip penetrometer (TR Italy model FFT 196) and the results were expressed in $\mathrm{kg}$. The soluble solids content (SSC) was determined through a digital refractometer and the results were expressed as Brix degrees. The fruits were considered ripe when firmness was $\leq 0.5 \mathrm{~kg}$ and the percentage of ripe fruits was calculated for each treatment.

A statistical analysis was carried out considering a completely randomized experimental design with five treatments, four replicates and five fruits per plot. The SANEST software (Zonta and Machado, 1984) was employed in the statistical analysis. The data were submitted to analysis of variance and the least significant differences were determined by using the Tukey's multiple range test.

\section{RESULTS AND DISCUSSION}

There was no significant interference of 1-MCP in the fruits' soluble solids content (SSC) during the storage period at $25^{\circ} \mathrm{C}$ (Figure 1). There was a notable increase in the SSC during exposure at room temperature. The SSC increased by almost $90 \%$ within a 4-day exposure period at $25^{\circ} \mathrm{C}$ after harvest, showing a continuous fruit ripening after harvest, which has been a characteristic of climacteric fruits. The increase in the SSC was probably due to the conversion of starch into soluble sugars, such as sucrose, fructose and glucose. Starch breakdown leading to soluble sugar production was reported by Paull et al. (1983) in soursop (Annona muricata L.) and by Prasanna et al. (2000) in custard apple. Fan et al. (1999) observed that non-treated apples did not differ from those treated with 1-MCP. The authors suggested that sensitivity to ethylene was not necessarily related to soluble solids accumulation in apple.

The fruits treated with $810 \mathrm{~nL} \mathrm{~L}^{-1}$ of 1-MCP presented higher firmness than control fruits during a 4-day period at $25^{\circ} \mathrm{C}$ (Figure 2). Firmness showed to be 50 to $60 \%$ higher in fruits treated with 1-MCP at this concentration when compared with non-treated fruits. The other concentrations were not effective at reducing the firmness loss. Fruit softening is considered to be one of the most sensible processes to ethylene in fruit ripening (Lelièvre et al., 1997a). Softening results from the breakdown of cell wall polysaccharides, which involves enzymatic activity. Paull et al. (1983) demonstrated an increase in the polygalacturonase (PG) and cellulase (endo-1.4, $\beta$-glucanase) activities during soursop (Annona muricata L.) ripening. More recently, Feng et al. (2000) verified that 1-MCP was capable of reducing the activity of these enzymes in avocado, thus retarding fruit softening. In the present work, 1-MCP at $810 \mathrm{~nL}$ $\mathrm{L}^{-1}$ probably reduced the activity of $\mathrm{PG}$ and cellulase, retarding the softening of custard apple. As regards the ripening progress, evaluated through firmness of fruits kept at room temperature, there was a noticeable delay in ripening when were treated with 270 or $810 \mathrm{~nL} \mathrm{~L}^{-1}$ of 1-MCP (Table 1). The ripening percentage rate 
(firmness $\leq 0.5 \mathrm{~kg}$ ) observed for fruits treated or not with 30 or $90 \mathrm{~nL} \mathrm{~L}^{-1}$ varied from 70 to $86 \%$ after 4 days at $25^{\circ} \mathrm{C}$ while fruits treated with higher concentrations of 1-MCP presented ripening percentage figures around $40 \%$ in the same period.
We found that 1-MCP could effectively retard the softening process in custard apple and prolong the fruits' shelf life. The lengthening of the period in which fruits remain firm can allow fruits to be transported through longer distances, as well as extend the marketing period.

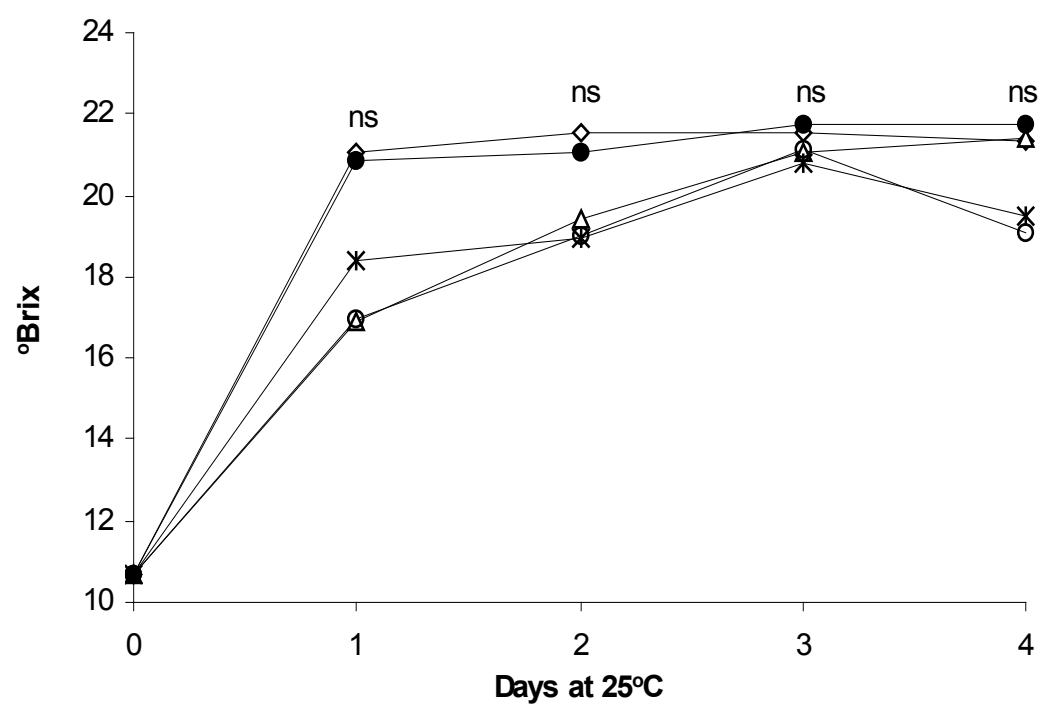

Figure 1 - Effect of 1-MCP on soluble solids content $\left({ }^{\circ}\right.$ Brix) of custard apple (Annona squamosa L.) stored at $25^{\circ} \mathrm{C} . \diamond 0 \mathrm{~nL} \mathrm{~L}{ }^{-1} ; \triangle 30 \mathrm{~nL} \mathrm{~L}^{-1} ; \bullet 90 \mathrm{~nL} \mathrm{~L}^{-1} ; * 270 \mathrm{~nL} \mathrm{~L}^{-1}$; o 810 $\mathrm{nL} \mathrm{L}{ }^{-1}$. Means separated by Tukey test at $\mathrm{P} \leq 0.05$.

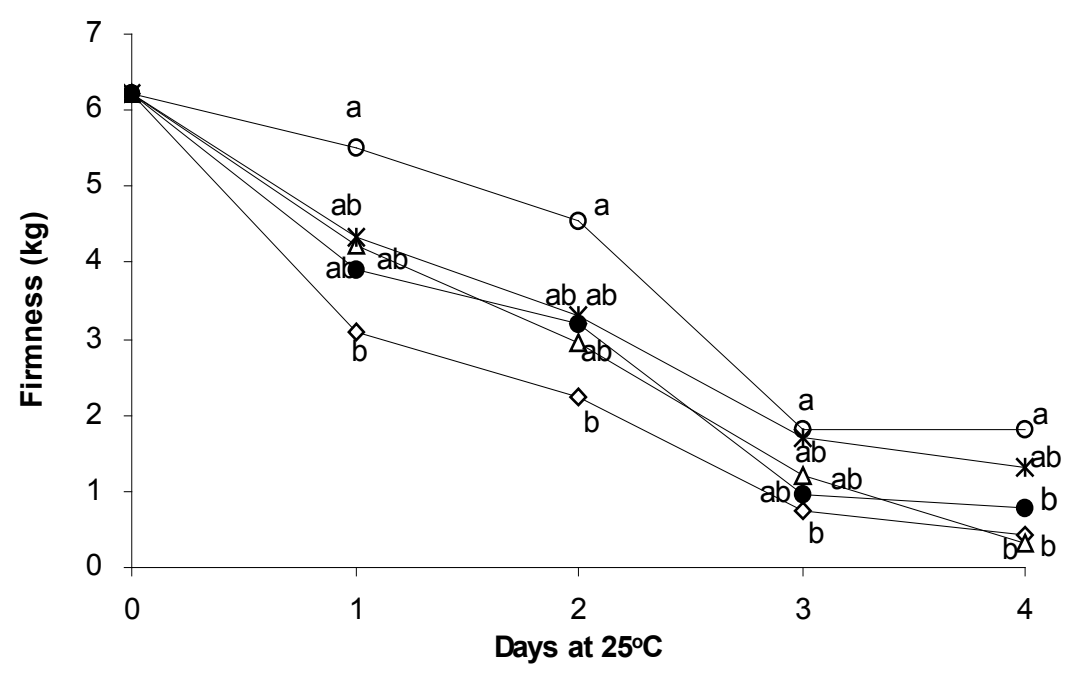

Figure 2 - Effect of 1-MCP on firmness (kg) of custard apple (Annona squamosa L.) stored at $25^{\circ} \mathrm{C} . \diamond 0 \mathrm{~nL} \mathrm{~L}^{-1} ; \triangle 30 \mathrm{~nL} \mathrm{~L}^{-1} ; \bullet 90 \mathrm{~nL} \mathrm{~L}^{-1} ; * 270 \mathrm{~nL} \mathrm{~L}^{-1} ;$ o $810 \mathrm{~nL} \mathrm{~L}^{-1}$. Means separated by Tukey test at $\mathrm{P} \leq 0.05$. 
Table 1 - Effect of 1-MCP on ripe fruits percentage for custard apple (Annona squamosa $\mathrm{L}$ ) stored at $25^{\circ} \mathrm{C}$.

\begin{tabular}{lcccc}
\hline $\begin{array}{l}1-\mathrm{MCP}^{-1} \\
\left(\mathrm{~nL} \mathrm{~L}^{-1}\right)\end{array}$ & 1 & \multicolumn{4}{c}{ Days at $25^{\circ} \mathrm{C}$} \\
\hline & & 2 & 3 & 4 \\
0 & 10 & $-------\%$ of ripe fruits ${ }^{*}------$ & 82 \\
30 & 0 & 16 & 31 & 86 \\
90 & 11 & 16 & 43 & 70 \\
270 & 0 & 19 & 41 & 41 \\
810 & 0 & 18 & 25 & 42 \\
\hline
\end{tabular}

*When firmness $\leq 0.5 \mathrm{~kg}$, fruits were considered ripe.

\section{RESUMO}

A pinha ou fruta do conde (Annona squamosa L.) apresenta reduzida vida de prateleira após a colheita, devido à rápida perda de firmeza de polpa. Este processo está associado à produção e à ação do etileno. Com o objetivo de retardar o amolecimento e a evolução do amadurecimento, pinhas foram tratadas com o antagonista da ação do etileno 1-metilciclopropeno (1-MCP) nas concentrações de $0,30,90,270$ e $810 \mathrm{~nL} \mathrm{~L}^{-1}$ durante 12 horas a $25^{\circ} \mathrm{C}$. Em seguida, os frutos foram armazenados a $25^{\circ} \mathrm{C}$ durante 4 dias. Durante este período foram determinados o teor de sólidos solúveis totais (SST), a firmeza de polpa e a porcentagem de frutos maduros $(\leq 0,5 \mathrm{~kg}$ de firmeza). Não houve efeito dos tratamentos sobre o teor de SST. Os frutos tratados com $810 \mathrm{~nL} \mathrm{~L}^{-1}$ de 1-MCP apresentaram maior firmeza de polpa que os frutos controle durante os 4 dias a $25^{\circ} \mathrm{C}$. Frutos não tratados ou tratados com 30 ou $90 \mathrm{~nL} \mathrm{~L}^{-}$ 1 apresentaram evolução mais rápida do amadurecimento se comparados aos frutos tratados com 1-MCP em maiores concentrações. Este antagonista do etileno apresenta potencial para uso comercial em pinhas, visando uma retenção do amadurecimento e prolongamento da vida útil à temperatura ambiente.

\section{REFERENCES}

Abdi, N.; McGlasson, W.B.; Holford, P.; Williams, M. andMizrahi, Y. (1998), Responses of climacteric and suppressed-climacteric plums to treatment with propylene and 1-methylcyclopropene. Postharvest Biology and Technology, 14, 29-39.

Blankenship, S. M. and Sisler, E. C. (1989), 2,5norbornadiene retards apple softening. HortScience, 24, 313-314.
Blankenship, S. M. and Sisler, E. C. (1993), Response of apples to diazocyclopentadiene inhibition of ethylene binding. Postharvest Biology and Technology, 3, 95-101.

Burg, S. P. and Burg, E. A. (1967), Molecular requirements for the biological activity of ethylene. Plant Physiology, 42, 144-152.

Fan, X.; Argenta, L. and Mattheis, J. P. (2000), Inhibition of ethylene action by 1-methylcyclopropene prolongs storage life of apricots. Portharvest Biology and Technology, 20, 135-142.

Fan, X.; Blankenship, S. M. and Mattheis, J. P. (1999), 1-methylcyclopropene inhibits apple ripening. Journal of the American Society for Horticultural Science, 124, 690-695.

Feng, X.; Apelbaum, A.; Sisler, E. C. and Goren, R. (2000), Control of ethylene responses in avocado fruit with 1-methylcyclopropene. Portharvest Biology and Technology, 20, 143-150.

Golding, J. B.; Shearer, D.; Wyllie, S. G. and McGlasson, W.B. (1998), Application of 1-MCP and propylene to identify ethylene-dependent ripening processes in mature banana fruit. Portharvest Biology and Technology, 14, 87-98.

Gong, Y. and Tian, M. S. (1998), Inhibitory effect of diazocyclopentadiene on the development of superficial scald in 'Granny Smith' apples. Plant Growth Regulation, 26117-121.

Jiang, Y.; Joyce, D. C. and Macnish, A. J. (1999), Extension of the shelf life of banana fruit by 1methylcyclopropene in combination with polyethylene bags. Postharvest Biology and Technology, 16, 187-193.

Lelièvre, J. M.; Latché, A.; Jones, B.; Bouzayen, M. and Pech, J. C. (1997a), Ethylene and fruit ripening. Physiologia Plantarum, 101, 727-739.

Lelièvre, J. M.; Tichit, L.; Dao, P.; Fillion, L.; Nam, Y. W.; Pech, J. C. and Latché, A. (1997b), Effects of chilling on the expression of ethylene biosynthetic genes in Passe-Crassane pear (Pyrus communis L.) fruits. Plant Molecular Biology, 33847-855. 
Pal, D. K. and Kumar, P. S. (1995), Changes in the physicochemical and biochemical composition of custard apple (Annona squamosa L.) fruits during growth, development and ripening. Journal of Horticultural Science, 70, 569-572.

Paull, R. E.; Deputy, J. and Chen, N.J. (1983), Changes in organic acids, sugars and headspace volatiles during fruits ripening of soursop (Annona muricata L.). Journal of the American Society for Horticultural Science, 108, 931-934.

Porat, R.; Halevy, A. H.; Serek, M. and Borochov, A. (1995), An increase in ethylene sensitivity following pollination is the initial event triggering an increase in ethylene production and enhanced senescence of Phalaenopsis orchid flowers. Physiologia Plantarum, 88, 243-250.

Prasanna, K. N. V.; Rao, D. V. S. and Krishnamurthy, S. (2000), Effect of storage temperature on ripening and quality of custard apple (Annona squamosa L.). Journal of Horticultural Science and Biotechnology, 75, 546-550.
Serek, M.; Sisler, E. C. and Reid, M. S. (1994), A volatile ethylene inhibitor improves the post harvest life of potted roses. Journal of the American Society for Horticultural Science, 119, 572-577.

Serek, M.; Sisler, E. C. and Reid, M. S. (1995), 1methylcyclopropene, a novel gaseous inhibitor of ethylene action, improves the life of fruit, cut flowers and potted plants. Acta Horticulturae, 394, 337-345.

Sisler, E. C. and Serek, M. (1997), Inhibitors of ethylene responses in plants at the receptors level: recent developments. Physiologia Plantarum, 100, 577-582.

Zonta, E. P. and Machado, A. A. (1984), Sistema de Análise Estatística para microcomputadores "SANEST" (software). Pelotas: UPFEL, Instituto de Física e Matemática. 